\title{
The Structutal Relationship among Authentic Leadership, Trust in Supervisor, Innovative Behavior and Organizational Citizenship Behavior
}

\author{
Park Jung Min ${ }^{1}$ and Seon Hee Ko ${ }^{2 *}$ \\ 'Department of Airline Service, Kyungwoon University, South Korea; \\ woo3834@naver.com \\ 2Department of Airline Service, Seowon University, South Korea; \\ sunny_ko@hanmail.net
}

\begin{abstract}
Background/Objectives: This study examines structural relationships among authentic leadership, trust in supervisor, innovative behavior and organizational citizenship behavior and it also aims to provide the effective implication for human resource management. Methods/Statistical Analysis: A convenience sample of 210 respondents was surveyed and a total of 195 usable questionnaires were analyzed. Since this study is a research on leadership perceived by subordinates, leaders such as people above pursers and managers were excluded from the survey. The analysis of research model used SPSS 21.0 and AMOS 22.0 to analyze the frequency of the data and conducted examination on research hypotheses through structural equation modeling. Findings: Through theoretical review, the study drew 3 hypotheses and collected data targeted at the flight attendants and ground service employees in the airlines. The results of the analysis are as follows. First hypothesis 1 suggesting that authentic leadership will have significant impact on trust in supervisor is adopted. Specifically, hypothesis 1 is showing .177 ( $\mathrm{t}$ value $=2.905$ ) of path coefficient and is adopted as $\mathrm{t}$ value meets a significant level ( $t$ value $\geqq \pm 1.96$ ). Second, hypothesis 2 indicating trust in supervisor will have significant impact on innovative behavior is adopted, showing .457 ( $t$ value $=5.521$ ) of path coefficient with significant $t$ value ( $t$ value $\geqq \pm 1.96$ ). Also, hypothesis 3 indicating trust in supervisor will have significant impact on organizational citizenship behavior is also adopted, showing .251( $\mathrm{t}$ value $=3.012$ ) of path coefficient with significant $t$ value ( $\mathrm{t}$ value $\geqq \pm 1.96$ ). Consequently, in this study all hypotheses are adopted at a significant level of 0.05. Application/Improvements: Authentic leadership is an exemplary leadership that induces internalization of organization members through showing a good example.
\end{abstract}

Keywords: Authentic Leadership, Innovative Behavior, Organizational Citizenship Behavior, Trust in Supervisor

\section{Introduction}

After the various incidents that put us into confusion recently, the necessity of research on the authentic leadership is being emphasized as there is a growing social demand for leadership based on authenticity and morality. Recently, as one of the methods for improving the performance and competitiveness of organization, an authentic leadership that emphasized the moral aspect is being spotlighted ${ }^{1,2}$. Authentic leaders have leadership that can prevent the disappointing and deceitful behaviors of the leaders that have caused a lot of problems. The members of an organization who perceive the authenticity of the leader tend to dedicate themselves into their

${ }^{*}$ Author for correspondence 
jobs and organizational activities more actively in return for the authenticity provided by the leader and make great achievements ${ }^{3}$.

If we examine the concept of trust, which has been studied as consequences of authentic leadership, Doney and Cannon (1997) referred to trust as the belief in the transaction partner and the determination to willingly embrace uncertainty in the transactions with the partner. Anderson and Narus(1990) defined trust as the belief that their transaction partner is honest and favorable ${ }^{5}$. The subordinates' trust in their supervisors plays a key role in the effectiveness of leadership and productivity of the $e^{6}$.

Innovative behavior means the process in which an individual develops new ideas and practices them by conducting specific behavior to make organizational achievements ${ }^{7}$. Innovative behavior related to an organization means behaviors that improve the job capability and eventually enhance the job performances by introducing new ideas and performing their job in an effective way ${ }^{8}$. Since the members of an organization are the main agents who perform organizational innovation, innovative behaviors of the organization members are the main target of management. Also, it bears great significance to do researches on the ways to motivate the organization members to conduct innovative behaviors?

Meanwhile, the concept of organizational citizenship behavior has been emphasized as extra role behaviors other than innovation and voluntary role ${ }^{10}$. Bateman and Organ (1983) has reviewed has reviewed the concepts that have been studied and referred to voluntary extra behaviors as organizational citizenship behaviors, which are not contractually specified for job conditions nor rewarded. Whitener, Brodt, Korsgaard and Werner (1998) Argued that the leader's authenticity, consistency in behavior, sharing and delegating control, and communication and consideration prompt trust from the subordinates. Walumbwa, Luthans, Avey and Oke (2011) claimed ${ }^{13}$ Claimed that authentic leadership prompts organizational citizenship behavior by building trust between the members, while Avolio, Gardner, Walumbwa, Luthans and May (2004) argued that authentic leaders gain confidence from the subordinates by showing personal care and respect for the members. Tan and Tan (2000) studied on trust in supervisors and innovative behavior targeted at company workers in America shows that the innovative behaviors for the development of the organization by members increase as the level of mutual trust between supervisors and subordinates goes up. Jeong (2005) argued in his analytic research on the influence factors which affect innovative behaviors that building trust with the leader encourages subordinates to suggest their opinions more comfortably and conduct innovative behaviors.

Konovsky and Pugh (1994) claimed that when the trust in the supervisor is robust, the subordinate tends to maintain quality relationship with the supervisor and conduct organizational citizenship behaviors to achieve the goal that the supervisor is seeking. Materson, Lewis, Goldman and Taylor (2000) argued that the quality of relationship between the supervisor and subordinate has positive $(+)$ relationship with organizational citizenship behavior.

Based on the above studies we can conclude that authentic leadership, trust in supervisor, innovative behavior and organizational citizenship behavior make significant relationships in which they affect each other. Therefore in this study, the following hypotheses are set based on the preceding studies which were suggested above.

$\mathrm{H}$ 1: Authentic leadership will have significant impact on trust in supervisor.

H 2: Trust in supervisor will have significant impact on innovative behavior.

H 3: Trust in supervisor will have significant impact on organizational citizenship behavior

The aviation service is composed of ground service that involves reservation, ticketing, and boarding, and flight service that is mainly provided by the cabin crew. Cabin service is provided in limited space led by a leader called purser in the airlines, which makes the leadership more important than other service jobs. Despite the importance, few researches have been done on authentic leadership in the airlines. Against this backdrop, this study examines the effects of authentic leadership on trust in supervisor, innovative behavior and organizational citizenship behavior, which will lead to suggestions of the effective methods for human resource management in the airlines.

\section{Data Collection and Analysis}

The survey was conducted targeting at the flight attendants and ground service employees of A airline in Korea through convenient sampling between August 15 and 
August 30 in 2015. A total of 230 questionnaires were distributed and 210 (91.3\%) were returned, among which $15(6.5 \%)$ were eliminated for their insufficient responses. $195(84.8 \%)$ were used as valid samples. Since this study is a research on leadership perceived by subordinates, leaders such as people above pursers and managers were excluded from the survey. The analysis of research model used SPSS 21.0 and AMOS 22.0 to analyze the frequency of the data and conducted examination on research hypotheses through structural equation modeling.

\section{Results}

\subsection{General Characteristics}

Table 1 shows the demographic characteristics of the respondents. Of the total respondents, 108 (55.4\%) are female and 87 (44.6\%) are male. For education, 'Graduate school' graduates are 33 (16.9\%) 'Undergraduate school' graduates are 146 (74.9\%), which is the most. By age, the respondents in their 30 s are 101 (51.8\%), which is larger

Table 1. General characteristics

\begin{tabular}{|c|c|c|c|}
\hline \multicolumn{2}{|c|}{ Distinction } & Frequency & Percentage \\
\hline \multirow{2}{*}{ Gender } & Female & 108 & 55.4 \\
\hline & Male & 87 & 44.6 \\
\hline \multirow{3}{*}{ Age } & $20 \sim 29$ & 72 & 36.9 \\
\hline & $30 \sim 39$ & 101 & 51.8 \\
\hline & 40 and above & 22 & 11.3 \\
\hline \multirow{2}{*}{ Working area } & Cabin service & 103 & 52.8 \\
\hline & Ground service & 92 & 47.2 \\
\hline \multirow{3}{*}{ Education } & 2-year college & 16 & 8.2 \\
\hline & Undergraduate school & 146 & 74.9 \\
\hline & Graduate school & 33 & 16.9 \\
\hline \multirow{4}{*}{ Duration of employment } & Less than 5 years & 75 & 38.5 \\
\hline & 5 years-less than 10 years & 44 & 22.6 \\
\hline & 10 years-less than 15 years & 37 & 19.0 \\
\hline & More than 15 years & 39 & 20.0 \\
\hline \multirow{3}{*}{ Position } & Contract worker & 32 & 16.4 \\
\hline & Regular worker & 80 & 41.0 \\
\hline & Assistant manager & 83 & 42.6 \\
\hline \multicolumn{2}{|c|}{ Total } & 195 & 100 \\
\hline
\end{tabular}


than 20s. And many of total respondents are regular workers and assistant managers.

\subsection{Reliability and Validity}

For the selection and elaboration of measurement categories, reliability analysis was conducted using AMOS 22.O.
Construct reliability with higher than 0.7 is generally recognized as high construct reliability in measurement categories and all factors used in this study were identified to have higher than $0.9^{19}$. The values of construct reliability are suggested in Table 2 . Next, confirmatory factor analysis was conducted to test the reliability of

Table 2. Confirmatory Factor Analysis (CFA) for the measurement model

\begin{tabular}{|c|c|c|c|c|}
\hline Factor & Measurement Category & $\begin{array}{l}\text { Std. factor } \\
\text { loading }\end{array}$ & t Value & SMC \\
\hline \multirow{4}{*}{$\begin{array}{l}\text { Authentic } \\
\text { leadership }\end{array}$} & $\begin{array}{l}\text { Supervisors listen carefully to other people's opinions before } \\
\text { making decisions }\end{array}$ & .687 & --- & .639 \\
\hline & Supervisors make decisions based on high ethical level & .837 & $13.118^{\star *}$ & .710 \\
\hline & Supervisors utilize feedback to enhance interaction with others & .716 & $11.612^{\star *}$ & .603 \\
\hline & Supervisors encourage subordinates to suggest opinions freely & .891 & $10.128^{\star *}$ & .552 \\
\hline \multirow{5}{*}{$\begin{array}{l}\text { Trust in } \\
\text { supervisor }\end{array}$} & $\begin{array}{l}\text { I am confident that my supervisors try to treat subordinates } \\
\text { fairly }\end{array}$ & .787 & --- & .619 \\
\hline & My supervisors do not try to benefit from lying subordinates. & .824 & $13.458^{\star *}$ & .700 \\
\hline & I trust my supervisors' diligence. & .811 & $12.873^{\star *}$ & .607 \\
\hline & I am very loyal to my supervisors. & .721 & $12.728^{\star *}$ & .616 \\
\hline & I support my supervisors in any circumstances. & .868 & $14.231^{\star *}$ & .793 \\
\hline \multirow{4}{*}{$\begin{array}{l}\text { Innovative } \\
\text { behavior }\end{array}$} & I think I am conducting innovative and creative behaviors. & .712 & --- & .619 \\
\hline & $\begin{array}{l}\text { I set up sufficient plans and schedule to conduct innovative } \\
\text { behavior. }\end{array}$ & .801 & $13.544^{\star *}$ & .700 \\
\hline & I often propose creative ideas. & .816 & $12.002^{\star *}$ & .667 \\
\hline & I investigate and secure the data needed to perform my ideas. & .733 & $12.248^{\star \star}$ & .626 \\
\hline
\end{tabular}


Table 2 Continued..,

\begin{tabular}{|c|c|c|c|c|}
\hline \multirow{4}{*}{$\begin{array}{c}\text { Organizational } \\
\text { citizenship } \\
\text { behavior }\end{array}$} & I try to be thoughtful not to cause problems with colleagues. & .883 & --- & .779 \\
\hline & I willingly help my colleagues who have a lot of workload. & .762 & $12.187^{\star *}$ & .580 \\
\hline & $\begin{array}{l}\text { I voluntarily participate in the events that boost the company's } \\
\text { image. }\end{array}$ & .774 & $12.434^{\star *}$ & .498 \\
\hline & I help new employees even when it's not my assigned job. & .708 & $11.923^{\star *}$ & .803 \\
\hline \multicolumn{5}{|c|}{$\chi^{2}=785.595(\mathrm{df}=309, \mathrm{p}=0.000), \chi^{2} / \mathrm{df}=2.542, \mathrm{RMR}=0.024, \mathrm{GFI}=0.893, \mathrm{AGFI}=0.854, \mathrm{NFI}=0.906, \mathrm{IFI}=0.918, \mathrm{CFI}=0.948^{* *}: \mathrm{P}<.01$} \\
\hline \multicolumn{5}{|c|}{$\begin{array}{c}\text { AVE: Authentic leadership } 0.576 \text {, Trust in supervisor } 0.589 \text {, Innovative behavior } 0.635 \text {, } \\
\text { Organizational citizenship behavior } 0.771\end{array}$} \\
\hline \multicolumn{5}{|c|}{$\begin{array}{c}\text { Construct reliability: Authentic leadership } 0.966 \text {, Trust in supervisor } 0.959 \text {, Innovative behavior } 0.945 \text {, } \\
\text { Organizational citizenship behavior } 0.963\end{array}$} \\
\hline
\end{tabular}

Table 3. Correlation matrix

\begin{tabular}{|c|c|c|c|c|}
\hline & A & B & C & D \\
\hline Authentic leadership: A & .759 & & & \\
\hline Trust in supervisor: B & .442 & .767 & & \\
\hline Innovative behavior: C & .275 & .622 & .797 & \\
\hline Organizational citizenship behavior: D & .554 & .422 & .567 & .878 \\
\hline
\end{tabular}

* all correlations are significant at $\mathrm{p}<0.01$ (2-tailed), diagonal value: square root AVE

measurement categories. When the fit indexes for model are strictly applied, it is considered that RMR should be lower than 0.05, GFI, NFI and CFI should be higher than 0.9 , and AGFI should be higher than $0.8^{19}$. Indexes in confirmatory factor analysis suggested in table 2 shows the model fit indexes after the categories which hinder the validity are removed. Model fit indexes were identified as $\chi^{2}=785.595(\mathrm{df}=309, \mathrm{p}=0.000), \chi^{2} / \mathrm{df}=2.542, \mathrm{RMR}=0.024$, GFI $=0.893, \quad$ AGFI $=0.854, \quad \mathrm{NFI}=0.906, \quad \mathrm{IFI}=0.918$,
CFI $=0.948$ and these values can be accepted except $\chi^{2}$ values ${ }^{20}$ which are sensitive to sample size.

Recommended values in Squared Multiple Correlation (SMC) values are higher than 0.5 in general and the categories which could not meet this condition were removed after convergent validity test. Total of 3 questions were regarded as convergent validity hindering category and removed. Removed questions are 'I explore new job techniques and ideas' (0.332) and 'I let other people suggest 
ideas and develop them' (0.398) in innovative behavior category, and 'I propose creative ideas to resolve customer complaints' (0.288) in organizational citizenship behavior category. All standardized factor loading values which are connected to items and related factors show higher than 0.5 and AVE which measures the explained dispersion by study unit is higher than 0.50 as well. Convergent validity in measured questions was identified as all $\mathrm{t}$-values showed higher than 1.96 of acceptance level ${ }^{21}$.

Discriminant validity means when individually different concepts are measured, correlation between obtained values should be low. In order to analyze the discriminant validity in measurement model as is suggested at below Table 3, square root AVE values and correlation coefficient values were compared and the discriminant validity was secured as the condition that 'square root AVE value should be larger than correlation coefficient value' was met $^{21}$. Through the above various analyses, reliability, convergent validity and discriminant validity in this study were verified.

\subsection{Testing the Conceptual Framework}

In this study, structure equation model was applied to identify examine the effects of authentic leadership on trust in supervisor, innovative behavior and organizational citizenship behavior. Examining the test results in overall structure model, the model with $\chi^{2}=374.829(\mathrm{p}=0.000)$, $\mathrm{GFI}=0.908, \mathrm{AGFI}=0.887, \mathrm{NFI}=0.901, \mathrm{RMR}=0.030$ was drawn. This model is considered to be appropriate because it shows appropriate levels when compared with general evaluation indexes in covariance structure analysis ${ }^{18}$. And standard chi-square index was approximately $2.4\left(\chi^{2}\right)$ $\operatorname{df}(152)=2.465)$ which showed very suitable Goodness of Fit. Test results of research hypotheses are like Table 4.

In detail, hypothesis testing result is as follows. First hypothesis 1 suggesting that authentic leadership will have significant impact on trust in supervisor is adopted. Specifically, hypothesis 1 is showing .177 ( $\mathrm{t}$ value $=2.905$ ) of path coefficient and is adopted as t value meets a significant level ( $t$ value $\geq \pm 1.96$ ). Second, hypothesis 2 indicating trust in supervisor will have significant impact on innovative behavior is adopted, showing $.457(\mathrm{t}$ value $=5.521)$ of path coefficient with significant $t$ value ( $t$ value $\geq \pm 1.96$ ). Also, hypothesis 3 indicating trust in supervisor will have significant impact on organizational citizenship behavior is also adopted, showing .251( $\mathrm{t}$ value $=3.012$ ) of path coefficient with significant $t$ value ( $t$ value $\geq \pm 1.96$ ). Consequently, in this study all hypotheses are adopted at a significant level of 0.05 .

Table 4. Structure model path analysis

\begin{tabular}{|c|c|c|c|c|c|}
\hline $\mathrm{H}$ & Path & Estimate & S.E & C.R & $\begin{array}{c}\mathrm{p} \\
\text { value }\end{array}$ \\
\hline 1 & $\begin{array}{c}\text { Authentic leadership--> } \\
\text { Trust in supervisor }\end{array}$ & .177 & .078 & $2.905^{\star *}$ & .003 \\
\hline 2 & $\begin{array}{l}\text { Trust in supervisor --> } \\
\text { Innovative behavior }\end{array}$ & .457 & .077 & $5.521^{\star *}$ & .000 \\
\hline 3 & $\begin{array}{c}\text { Trust in supervisor --> } \\
\text { Organizational citizenship } \\
\text { behavior }\end{array}$ & .251 & .064 & $3.012^{\star *}$ & .000 \\
\hline
\end{tabular}

${ }^{* *}:=\mathrm{t}$-statistic $(\geq 1.96)$ sig. level of $\mathrm{p}<0.05$ 


\section{Discussion}

This study examined the structural relationship among authentic leadership, trust in supervisor, innovative behavior and organizational citizenship behavior perceived by airline service employees. It also aims to provide the effective implications for human resource management in airlines. Through theoretical review, the study drew 3 hypotheses and the study results through empirical analysis are as follows:

First, hypothesis 1 that authentic leadership will have significant impact on trust in supervisor has been adopted. This means that as leaders made decisions based on high ethical standards and listen carefully to other opinions before making decisions, it leads to the high recognition of authentic leadership and eventually high trust in supervisors. Authentic leadership puts high emphasis on modeling of leaders' positive roles unlike transformational leadership, ethical leadership and servant leadership models suggested earlier. Authentic leadership is an exemplary leadership that induces internalization of organization members through showing a good example. It suggests new implications in that it prompts the self-development of the leaders. When the leaders of each team constantly reflect on themselves and have clear values and inner thoughts, the trust in supervisors builds up.

Second, hypothesis 2, trust in supervisor will have significant impact on innovative behavior has been adopted. As subordinates have strong loyalty toward the supervisor and high recognition of the supervisors' hard work, they tend to conduct creative and innovative behaviors. Also, the subordinates who support their supervisors in any circumstances tend to explore new job techniques and ideas and help other people to perform innovative behaviors. As a way of enhancing trust in supervisors, it is necessary to build a culture in which the difficulties of employees are heard and solved formally and informally in a company. Methods such as small group activities and mentoring will be effective in solving problems and helpful for building trust in supervisor. In terms of management of human resource in the airlines, the executive officers in the airlines need to create organizational atmosphere in which employees are encouraged to have confidence through trust in supervisor and able to suggest their ideas.

Third, hypothesis 3 , trust in supervisor will have significant impact on organizational citizenship behavior has been adopted. This means that as the trust in supervisor is higher, subordinates tend to conduct organizational citizenship behavior more, which is a voluntary work outside of their role, even though it is not formally rewarded. That is, as the employees have high recognition of trust in supervisors, they tend to willingly help other workers who have a lot of workload and participate voluntarily in the events that enhance company's image. Also, they help newly-employed workers to adjust to their jobs and show thoughtful actions not to cause problems with their colleagues. Since strengthening trust in supervisors brings positive results of the organization's performance, it is necessary to develop programs that can build organizational culture and atmosphere in which mutual trust between the members and their supervisors is encouraged.

This study collected data targeting at Asiana airlines among all the domestic airlines in Korea. Further researches will examine the relationship between authentic leadership and other factors targeting at low cost carriers, whose market share in domestic and international flights is increasing annually. This will give significant implications as we compare it with the results of this study.

\section{References}

1. Hwang YK, Lee CS. Structural relationship between authentic leadership, organizational communication, organizational effectiveness and psychological capital of office workers. Indian Journal of Science and Technology. 2015 April; 8(7):292-98. DOI: 10.17485/ijst/2015/v8iS7/69993.

2. Hong SH. An analysis of the structural relationships between authentic leadership of the CEO of small and medium business, learning organization, positive psychological capital of the employees and organizational effectiveness. Unpublished doctoral dissertation. Soongsil University. 2011; 8(7):1-7.

3. Sherwood J, Yoo S. The Relationship between self-leadership, self-efficacy and authentic leadership. Journal of Brain Education. 2012; 10(1):75-104.

4. Doney PM, Canon JP. An examination of the nature of trust in buyer -seller relationships. Journal of Marking. 1997; 61(2):35-61.

5. Anderson JC, Narus JA. A model of distributor firm and manufacturer firm partnerships. Journal of Marketing. 1990; 54(1):42-58.

6. Kouzes JM, Posner BZ. Credibility: How leaders gain and lose it, why people demand it. SanFrancisco, Jossy-Bass Publishers; 1993. p. 272. 
7. Scott SG, Bruce RA. Determinants of innovative behavior: A path model of individual innovation in the workplace. Academy of Management Journal. 1994; 37(3):580-607.

8. Farr JL, Ford CM. Individual innovation, innovation and creativity at work. New York: NY, Willey; 1990.

9. Song JS, Yang PS, Willey NY . Mediating effects of psychological empowerment on the relationship between organizational justice and innovative behavior. Korean Academy of Human Resources Management. 2008; 15(3):63-87.

10. Katz D, Kahn RL. The social psychology of organizations. New York, Wiley; 1978. p. 1-23.

11. Bateman TS, Organ DW. Job satisfaction and the good soldier: The relationship between affect and employee citizenship. Academy of Management Journal. 1983; 26(4):587-95.

12. Whitener E, Brodt S, Korsgaard MA, Werner J. Managers as initiators of trust: An exchange relationship for understanding managerial trustworthy behavior. Academy of Management Journal. 1998; 23(1):513-30.

13. Walumbwa FO, Luthans F, Avey JB, Oke A. Authentically leading groups : The mediating role of collective psychological capital and trust. Journal of Organizational Behavior. 2011; 32(1):42-24.

14. Avolio BJ, Gardner WL, Walumbwa FO, Luthans F, May DR. Unlocking the mask: A look at the process by which authentic leaders impact follower attitudes and behaviors. The Leadership Quarterly. 2004; 15(6):801-23.

15. Tan H, Tan C. Toward the differentiation of trust in supervisor and trust in organization. Genetic Social \& General Psychology Monographs. 2000; 126(2):241-61.

16. Chung YJ. The analysis of effective factor for reforming behavior: focused on organizational support, leader-member exchange s and performance incentive payment. Master's Thesis. Chung-Ang University. 2005; 87(3):1-9.

17. Konovsky MA, Pugh SD. Citizenship behavior and social exchange. Academy of Management Journal. 1994; 37(3):656-69.

18. Materson SS, Lewis K, Goldman, BM, Taylor MS. Integrating justice and social exchange: the differing effects of fair procedures and treatment on work relationship. Academy of Management Journal. 2000; 43(1):738-48.

19. Hair JE, Anderson RE, Tatham RL, Black WC. Multivariate data analysis. Fifth Edition, Prentice-Hall International Inc; 1998.

20. Bagozzi RP, Yi Y. On the evaluation of structural equation models. Journal of the Academy of Marketing Science. 1988; 16(1):74-94.

21. Fornell C, Larker DF. Evaluating structural models with unobservable variables and measurement error. Journal of Marketing Research. 1981 Feb; 18(1):39-50. 